\title{
The Enhancement of Uranium and Thorium in Bangka Tin Slag
}

\author{
S. Permana ${ }^{1 *}$, J.W. Soedarsono ${ }^{1}$, A. Rustandi ${ }^{1}$, A. Maksum ${ }^{2}$, K.S. Widana ${ }^{3}$, \\ K. Trinopiawan ${ }^{3}$ and M. Anggraini ${ }^{3}$ \\ ${ }^{I}$ Centre of Mineral Processing and Corrosion Research, Department of Metallurgy and Materials, \\ University of Indonesia, Depok 16424, Indonesia \\ ${ }^{2}$ Department of Mechanical Engineering, Jakarta State Polytechnic, Depok 16425, Indonesia \\ ${ }^{3}$ Center of Nuclear and Mineral Technology, National Nuclear Energy Agency, \\ Jl. Lebak Bulus Raya No. 49, Jakarta 12440, Indonesia
}

\section{ARTICLE INFO}

Article history:

Received 3 October 2016

Received in revised form 24 January 2018

Accepted 25 January 2018

Keywords:

Bangka tin slag

Dissolution

Pre-removed

Thorium

Uranium

\begin{abstract}
A B S T R A C T
Several studies have indicated that consumer goods, air pollution, and by-products, residues, and waste products of natural resources exploitation contain uranium and thorium. In this research, the enhancement of these two metals resulted from the extraction process of Bangka tin slag. To deal with the enhancement of uranium and thorium, Bangka tin slag (BTS) was dissolved in hydrofluoric acid (HF), hydrochloric acid $(\mathrm{HCl})$, and sodium hydroxide $(\mathrm{NaOH})$. The result shows that Bangka tin slag has high contents of uranium, 3404 ppm, and thorium, 25850 ppm, which were achieved through the dissolution of BTS-roasting-quenching-sieving (BTS-RQS) residues in $\mathrm{HF} 8 \%, \mathrm{HCl} 6 \mathrm{M}$, and $\mathrm{NaOH} 10 \mathrm{M}$.
\end{abstract}

(C) 2018 Atom Indonesia. All rights reserved

\section{INTRODUCTION}

The Regulation number 16 year 2013 on Radiation Safety in the Storage of Technologically Enhanced Naturally Occurring Radioactive Material issued by BAPETEN (Nuclear Energy Regulatory Agency of Indonesia) stipulates that the maximum permissible concentration of uranium and thorium is only $1 \mathrm{~Bq} / \mathrm{g}$, equivalent to $3 \mathrm{ppm}$ uranium and $10 \mathrm{ppm}$ thorium [1].

Research on historical tin and bronze artifacts from all over South Africa showed that their prime radioisotopes came from cassiterite where the tin ore evolved after crystallization through the decay of uranium $(\mathrm{U})$ and thorium $(\mathrm{Th})$ to lead $(\mathrm{Pb})$, due to the high $\mathrm{U} / \mathrm{Pb}$ ratio and other minerals [2]. A NORM site located in one of the largest rare earth deposits, Baotou, Inner Mongolia, China, has a radioactive content of 0.01-0.05 \% $\mathrm{ThO}_{2}$ and 0.0005-0.002\% $\mathrm{U}_{3} \mathrm{O}_{8}$. Converting blast furnace iron slag into cement, concrete, and bricks, or using it for road construction, has raised environmental issues.

\footnotetext{
*Corresponding author.

E-mail address: sulaksana@yahoo.com

DOI: https://doi.org/10.17146/aij.2018.529
}

Thus, a NORM regulatory control is very important for taking effective measures to lower its doses [3]. In Malaysia, monazite, zircon, xenotime, ilmenite, and several other minerals were obtained from tin tailings and processed further into concentrated minerals. The result of an investigation showed that the concentrated minerals contained uranium and thorium with highest concentrations of $4053 \pm 428 \mathrm{ppm}$ and $33578 \pm 873 \mathrm{ppm}$ respectively [4]. Tin mining in Bangka Belitung Islands, Indonesia, caused the area to exhibit a higher natural radioactivity than normal areas. Research on food crops, which are the main source of exposure to internal radiation on humans, showed that the consumption of radionuclide in food was $0.205 \mathrm{mSv} /$ year, far lower than the annual dose limit for the public of $1 \mathrm{mSv}$ [5]. In addition to Bangka Belitung, rocks and soil in Mamuju, Sulawesi, Indonesia were known to have a high level of natural uranium and thorium radiation. It was found that the area with high thorium and uranium concentrations was related to a multi-geology process [6].

The assessment of toxic metal exposure on environment also involved biomonitoring of sewage that consisted of urine, blood, and hair [7]. 
To replace the imported health physics instruments, a contamination monitor was designed for detecting beta and gamma radiations emitted by radioactive materials. Indicator lamps were used to show the status of the contamination. If the value exceeded the specified levels, the monitor would provide an alarm and display the readings in the meter panel [8].

A measurement procedure with inductivelycoupled plasma optical emission spectrometry (ICP-OES) can determine rare-earth metals in samples rich in tantalum and niobium. The procedure can also be applied to detect $\mathrm{Nb}, \mathrm{Ta}$, $\mathrm{Ti}, \mathrm{Zr}, \mathrm{Sn}, \mathrm{Th}$, and $\mathrm{U}$ in a single stable solution high in tantalum and niobium [9]. X-ray fluorescence (XRF) analysis was used to characterize uranium and thorium, following the standard addition quantification method. In the calibration graph, the $\mathrm{R}^{2}$ for uranium was 0.9997 and the $\mathrm{R}^{2}$ of thorium was 0.9915 . To normalize the quantification of all other prepared samples, a visible vibration method was put to give more accurate results [10]. Tin slag samples from Butterworth were characterized with energy dispersive X-ray fluorescence (EDXRF). From those samples were obtained $60 \mathrm{ppm}$ uranium and $160 \mathrm{ppm}$ thorium [11]. A study on tin slag II smelting by-products found it to contain $0.0619 \%$ of $\mathrm{U}_{3} \mathrm{O}_{8}$ and $0.53 \%$ of $\mathrm{ThO}_{2}$ [12]. The enrichment of BTS metal oxides indicated an increase in uranium and thorium contents [13]. Slag study increasingly flourished because of the environmental impact of both ferrous and nonferrous slag [14].

All the measures were taken to separate radioactive and rare-earth elements in Bangka tin slag (henceforth referred to as BTS). The result showed that the two element groups could be separated through a three-stage process. The first was a $700{ }^{\circ} \mathrm{C}$ smelting with $\mathrm{NaOH}$ to produce silicafree hydroxide cake with $64.90 \%$ sedimented uranium, $56.23 \%$ thorium, and $67.67 \%$ rare-earth metals. The second stage was leaching with $\mathrm{H}_{2} \mathrm{SO}_{4}$, and the third one was the extraction with $\mathrm{H}_{2} \mathrm{C}_{2} \mathrm{O}_{4}$ accompanied by $\mathrm{NH}_{4} \mathrm{OH}$. Leaching hydroxide cake with $\mathrm{H}_{2} \mathrm{SO}_{4}$ aimed to extract radioactive elements from rare-earth elements. This produced precipitate of sodium-rare earth sulfate $\mathrm{NaREE}\left(\mathrm{SO}_{4}\right)_{2}$ and solution of uranium-thorium sulfate with $27.01 \%$ dissolved uranium and $61.67 \%$ thorium. On the other hand, rare-earth element content was only $1 \%$. ICP-OES analysis indicated that the reaction condition of uranium-thorium sulfate with the addition of $2.4 \mathrm{mmol}_{2} \mathrm{C}_{2} \mathrm{O}_{4}$ and $32.15 \mathrm{mmol}$ $\mathrm{NH}_{4} \mathrm{OH}$ played as the optimum condition of uranium and thorium separation. In these conditions, the precipitate contained $\mathrm{Th}\left(\mathrm{C}_{2} \mathrm{O}_{4}\right)_{2}$ and $\mathrm{UO}_{2} \mathrm{C}_{2} \mathrm{O}_{4}$ solution [1].

According to our latest informal discussion in 2015, the amount of BTS output of PT Timah Tbk was approximately $360 \mathrm{t} / \mathrm{mo}$ while the BTS volume at the stockyard was about $129000 \mathrm{t}$. Based on the calculation, assuming the minimum production of tin of $35000 \mathrm{t} / \mathrm{a}$ [15], BTS can be predicted to reach around $10 \%$ [16], or equal to $3500 \mathrm{t} / \mathrm{a}$ of tin production. The contents of uranium and thorium in BTS enable us to have a secondary source that can be processed by reducing the contents of other oxides in it.

From the reviews above, no researchers explored how to enhance the contents of uranium and thorium in Bangka tin slag through hydrofluoric acid ( $\mathrm{HF})$, hydrochloric acid $(\mathrm{HCl})$, and sodium hydroxide $(\mathrm{NaOH})$ dissolution, and roastingquenching-sieving (RQS).

This study investigates the enhancement of Bangka tin slag. The highest contents of the two metals can be known through the characterization of radioactive elements in (1) BTS and BTS-RQS (BTS-RQS dissolution into hydrofluoric acid), (2) BTS-RQS dissolution in hydrochloric acid, continued in sodium hydroxide, (3) BTS-RQS dissolution in acid fluoride, continued in hydrochloric acid and sodium hydroxide, and (4) chemical composition analysis using XRF and ultraviolet-visible spectrophotometry (UV-Vis).

\section{EXPERIMENTAL METHODS}

The materials used were as in previous studies [13]. Currently, BTS was characterized by SEM (scanning electron microscope) and EDS (energy dispersive X-ray spectroscopy), using FEI Inspect F50 SEM and EDAX EDS, while the samples of BTS and BTS-RQS, as well as the characterization of dissolved chemical composition, involved UV-Vis (Shimadzu UV-2101PC scanning spectrophotometer).

Previous investigations applied the procedure of pre-removed other oxides including samples F4, F8, A6B6, and A6B10 [13]. Henceforth, this study uses abbreviations $\mathrm{MOO}$ and EMO. MOO is a short form of major other oxides comprised of $\mathrm{SiO}_{2}, \mathrm{CaO}$, $\mathrm{TiO}_{2}, \mathrm{Al}_{2} \mathrm{O}_{3}, \mathrm{Fe}_{2} \mathrm{O}_{3}$, and $\mathrm{ZrO}_{2}$. EMO stands for elements and other minor oxides not present in MOO, uranium, and thorium.

A dissolution procedure for $\mathrm{F} 4, \mathrm{~F} 8, \mathrm{~A} 6 \mathrm{~B} 6$, A6B10, F4-A6B10, and F8-A6B10 was performed as in Table 1. 
Table 1. Sample code, solvent type, concentration $(\% / \mathrm{M})$ and dissolution time (hours)

\begin{tabular}{|c|c|}
\hline $\begin{array}{l}\text { Sample } \\
\text { Code }\end{array}$ & $\begin{array}{l}\text { Type of solvent, concentration }(\% / \mathrm{M}) \text {, and } \\
\text { dissolution time }(\mathrm{h})\end{array}$ \\
\hline F8 & $\mathrm{HF} 8 \%, 2 \mathrm{~h}$ \\
\hline F16 & $\mathrm{HF} 16 \%, 2 \mathrm{~h}$ \\
\hline A6B6 & $\mathrm{HCl} 6 \mathrm{M}, 2 \mathrm{~h}$ - next dissolution with $\mathrm{NaOH} 6 \mathrm{M}, 20 \mathrm{~h}$ \\
\hline A6B10 & $\mathrm{HCl} 6 \mathrm{M}, 2 \mathrm{~h}-$ next dissolution with $\mathrm{NaOH} 10 \mathrm{M}, 20 \mathrm{~h}$ \\
\hline F4-A6B10 & $\begin{array}{l}\mathrm{HF} 4 \%, 2 \mathrm{~h} \text { - next dissolution with } \mathrm{HCl} 6 \mathrm{M}, 2 \mathrm{~h} \text {, last } \\
\text { dissolution with } \mathrm{NaOH} 10 \mathrm{M}, 20 \mathrm{~h}\end{array}$ \\
\hline F8-A6B10 & $\begin{array}{l}\mathrm{HF} 8 \%, 2 \mathrm{~h} \text { - next dissolution with } \mathrm{HCl} 6 \mathrm{M}, 2 \mathrm{~h} \text {, last } \\
\text { dissolution with } \mathrm{NaOH} 10 \mathrm{M}, 20 \mathrm{~h}\end{array}$ \\
\hline
\end{tabular}

\section{RESULTS AND DISCUSSION}

The results of the initial characterization of BTS using XRF are shown in Table 2. The table represents $\mathrm{SiO}_{2}$, at $34.26 \%$, as the most prevalent content of MOO.

Table 2. Results of chemical analysis of the Bangka tin slag [6]

\begin{tabular}{ccccccccc}
\hline $\begin{array}{c}\mathrm{Th} \\
(\mathrm{ppm})\end{array}$ & $\begin{array}{c}\mathrm{U} \\
(\mathrm{ppm})\end{array}$ & $\begin{array}{c}\mathrm{SiO}_{2} \\
(\%)\end{array}$ & $\begin{array}{c}\mathrm{CaO} \\
(\%)\end{array}$ & $\begin{array}{c}\mathrm{TiO}_{2} \\
(\%)\end{array}$ & $\begin{array}{c}\mathrm{Al}_{2} \mathrm{O}_{3} \\
(\%)\end{array}$ & $\begin{array}{c}\mathrm{Fe}_{2} \mathrm{O}_{3} \\
(\%)\end{array}$ & $\begin{array}{c}\mathrm{ZrO}_{2} \\
(\%)\end{array}$ & $\begin{array}{c}\mathrm{EMO} \\
(\%)\end{array}$ \\
\hline 2.028 & 276 & 34.26 & 15.44 & 11.92 & 11.7 & 8.84 & 4.78 & 12.06 \\
\hline
\end{tabular}

Results of characterization of BTS using SEM-EDS are given in Fig. 1. The SEM-EDAX characterization shows three different values of silicon contents, $12.07 \mathrm{wt} \%$ in Fig. 1(a), 12.79 wt \% in Fig. 1(b), and 12.84 wt \% in Fig. 1(c). On the other hand, MOO was found to contain $\mathrm{Ca}$, $\mathrm{Ti}, \mathrm{Al}, \mathrm{Fe}$, and $\mathrm{Zr}$.

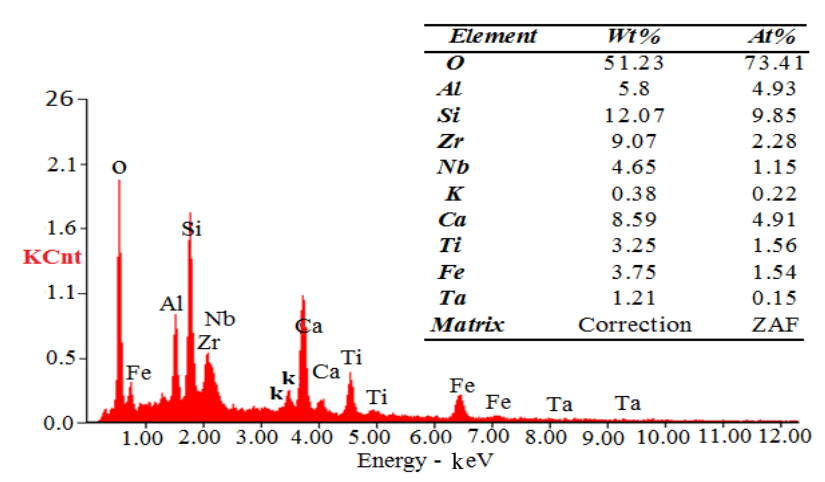

(a)

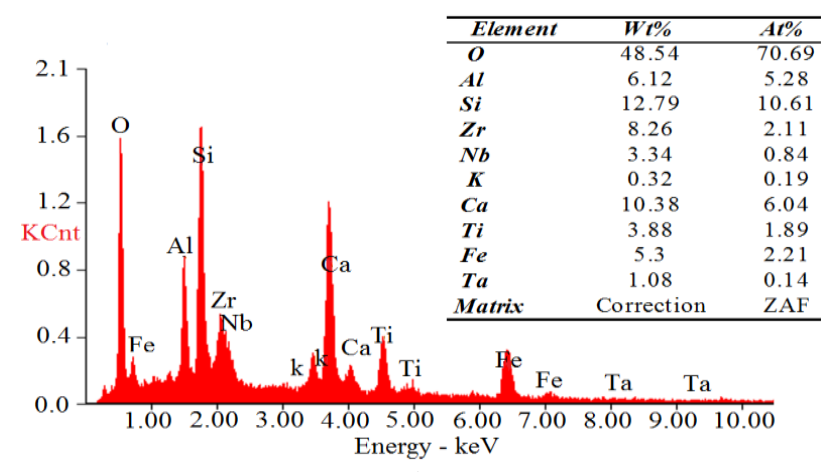

(b)

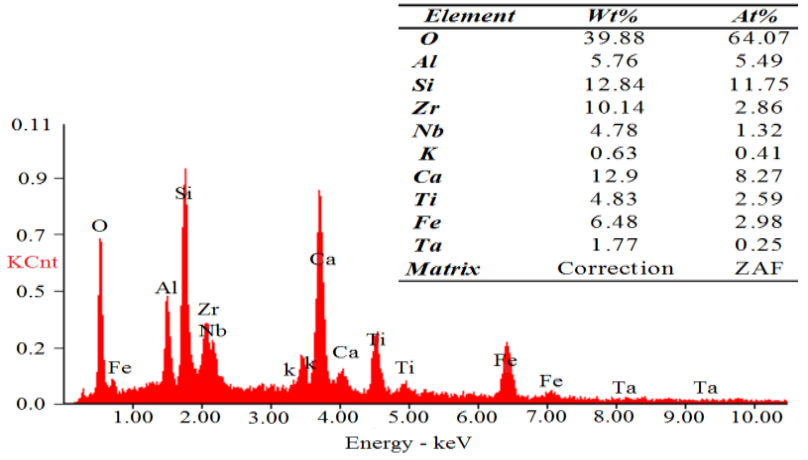

(c)

Fig. 1. Points of observation in sample with SEM-EDAX characterization.

Using X-ray diffraction, samples F4-A6B10 and F8-A6B10 were characterized and the results are represented in Fig. 2.

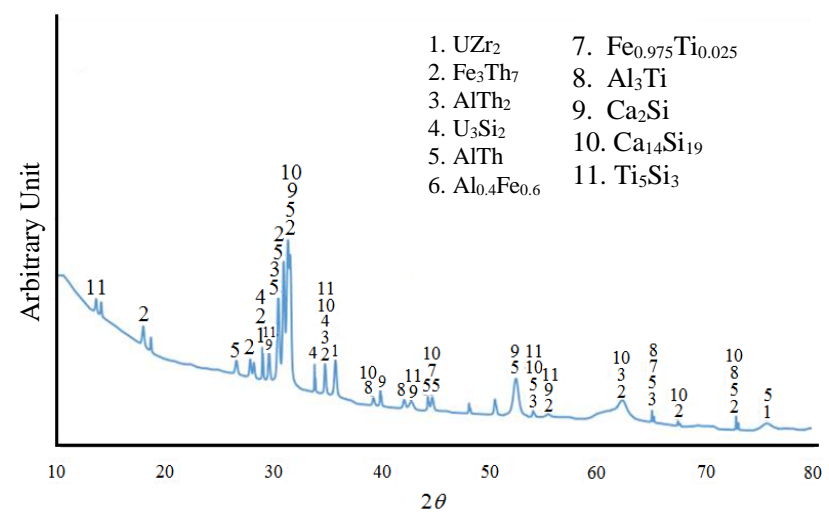

(a)

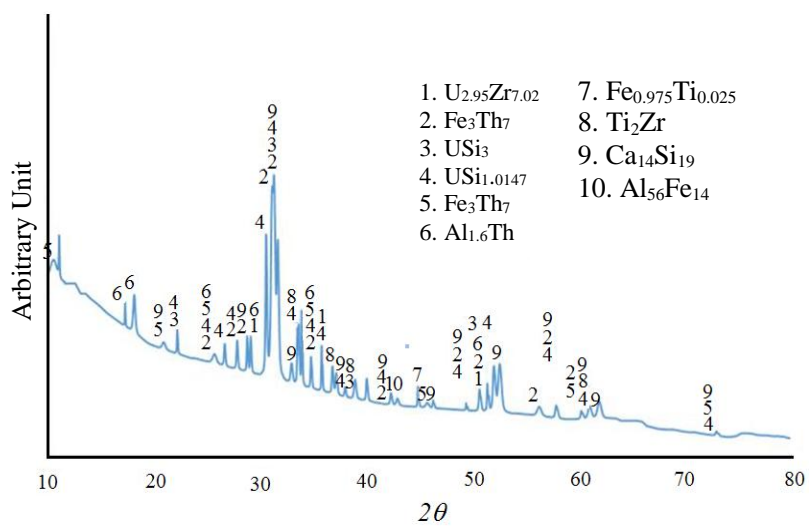

(b)

Fig. 2. XRD characterization results on samples with code of (a) F4-A6B10 and (b) F8-A6B10.

Sample F4-A6B10 shows an uranium compound $\mathrm{UZr}_{2}$ at the peaks $2 \theta$ of $28.9^{\circ}, 35.6^{\circ}$, and $75.6^{\circ}$. Thorium compounds appeared in $\mathrm{Fe}_{3} \mathrm{Th}_{7}$, $\mathrm{AlTh}_{2}$, and AlTh. Among all, $\mathrm{Fe}_{3} \mathrm{Th}_{7}$ has dominant peaks in $2 \theta: 17.8^{\circ}, 27.8^{\circ}, 28.9^{\circ}, 30.8^{\circ}, 31.3^{\circ}, 34.7^{\circ}$, $55.3^{\circ}, 62.3^{\circ}, 67.4^{\circ}$, and $72.8^{\circ}$. Sample F8-A6B 10 reflects the uranium compounds in $\mathrm{U}_{2.98} \mathrm{Zr}_{7.02}, \mathrm{USi}_{3}$, and $\mathrm{USi}_{1.0147}$. USi $i_{1.0147}$ is the only compound whose 
dominant peaks are in $2 \theta: 22^{\circ}, 25.5^{\circ}, 26.5^{\circ}, 27.7^{\circ}$, $30.4^{\circ}, 31.2^{\circ}, 33.7^{\circ}, 34.6^{\circ}, 35.7^{\circ}, 37.8^{\circ}$, and $42.2^{\circ}$. Thorium compounds emerged from $\mathrm{Fe}_{3} \mathrm{Th}_{7}$ and $\mathrm{Al}_{1.6} \mathrm{Th}$. The former has dominant peaks in $2 \theta$ : $10.4^{\circ}, 20.8^{\circ}, 25.5^{\circ}, 34.6^{\circ}, 45.5^{\circ}, 49.2^{\circ}, 51.8^{\circ}, 57.7^{\circ}$ $60.1^{\circ}, 60.8^{\circ}$, and $72.8^{\circ}$.

Samples F4-A6B10 and F8-A6B10 illustrated how easily uranium attached to zircon as in $\mathrm{UZr}_{2}$ and $\mathrm{U}_{2.98} \mathrm{Zr}_{7.02}$. As for thorium, its compound often involves iron as in $\mathrm{Fe}_{3} \mathrm{Th}_{7}$.

The principle of upgrading uranium and thorium in this research is that dissolving other oxides (MOO and EMO) can increase uranium and thorium contents. The peaks in Fig. 1 (a), Fig. 1 (b), and Fig. 1 (c) are relatively similar and this illustrates the dominance of MOO.

A characterization using UV-Vis spectrophotometer resulted in (1) $72.90 \mathrm{mg} / \mathrm{L}$ thorium, in which the dilution factor was 250 times, and (2) $218.50 \mathrm{mg} / \mathrm{L}$ uranium, in which the dilution factor was 12.5 . The concentration of the two minerals led their contents in BTS to be $18225 \mathrm{ppm}$ and $2731 \mathrm{ppm}$, respectively. Table 2 shows the results of BTS characterization using XRF. In this case, the thorium and uranium contents are $2028 \mathrm{ppm}$ and 276 ppm, respectively.

The characterization of elements with low contents should not use XRF because the obtained results are semi-quantitative. This piece of information can be considered as a revision of the characterization of chemical composition in previous research [11,17].

Silica has a high melting point, making it difficult to dissolve in a pyrometallurgical process. Dissolving silica in hydrofluoric acid produces volatile silicon tetrafluoride, as in eq. (1).

$$
\mathrm{SiO}_{2}+4 \mathrm{HF} \rightarrow \mathrm{SiF}_{4}+2 \mathrm{H}_{2} \mathrm{O} \quad \Delta \mathrm{G}=-24.194 \mathrm{kcal}
$$

Table 3 shows the enhancement of $\mathrm{SiO}_{2}$ through dissolution with higher concentration of hydrofluoric acid. This was described in a previous study [18]. In $16 \%$ hydrofluoric acid, XRF analysis resulted in $1.172 \% \mathrm{SiO}_{2}$.

Table 3. Results of chemical analysis of MOO and EMO in Bangka tin slag after treatment [6]

\begin{tabular}{cccccccc}
\hline $\begin{array}{c}\text { Sample } \\
\text { code }\end{array}$ & $\begin{array}{c}\mathrm{SiO}_{2} \\
(\%)\end{array}$ & $\begin{array}{c}\mathrm{CaO} \\
(\%)\end{array}$ & $\begin{array}{c}\mathrm{TiO}_{2} \\
(\%)\end{array}$ & $\begin{array}{c}\mathrm{Al}_{2} \mathrm{O}_{3} \\
(\%)\end{array}$ & $\begin{array}{c}\mathrm{Fe}_{2} \mathrm{O}_{3} \\
(\%)\end{array}$ & $\begin{array}{c}\mathrm{ZrO}_{2} \\
(\%)\end{array}$ & $\begin{array}{c}\mathrm{EMO} \\
(\%)\end{array}$ \\
\hline $\mathrm{F} 8$ & 3.349 & 15.670 & 12.450 & 6.131 & 4.672 & 8.773 & 46.915 \\
$\mathrm{~F} 16$ & 1.172 & 25.530 & 1.236 & 9.301 & 2.843 & 10.600 & 49.064 \\
$\mathrm{~A} 6 \mathrm{~B} 6$ & 22.270 & 13.580 & 16.800 & 7.499 & 12.470 & 8.282 & 17.358 \\
$\mathrm{~A} 6 \mathrm{~B} 10$ & 22.060 & 12.650 & 18.640 & 6.906 & 12.380 & 8.370 & 17.243 \\
\hline
\end{tabular}

Dissolution with hydrochloric acid followed by sodium hydroxide did not show a significant reduction in $\mathrm{MOO}$ and $\mathrm{EMO}$ with the same increase of $\mathrm{NaOH}$ contents as that of hydrochloric acid. In this research, $\mathrm{Ta}_{2} \mathrm{O}_{5}$ and $\mathrm{Nb}_{2} \mathrm{O}_{5}$ recovery of tin slag and the contents of $\mathrm{Ta}_{2} \mathrm{O}_{5}$ and $\mathrm{Nb}_{2} \mathrm{O}_{5}$ have approximately twice the yield ratio if the particle size is smaller than $0.150 \mathrm{~mm}$ or the particle size between 0.180 and $0.150 \mathrm{~mm}$ in hydrochloric acid dissolution is followed by sodium hydroxide [19].

BTS-RQS in Fig. 3 does not show changes in the thorium contents. Thorium contents in BTS and BTS-RQS were $18225 \mathrm{ppm}$ and $18300 \mathrm{ppm}$ respectively.

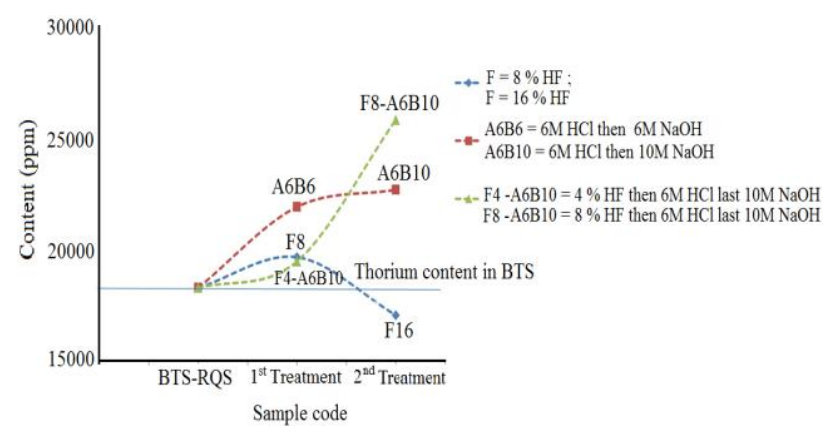

Fig. 3. Thorium content in BTS residue with various treatment conditions.

The thorium contents in sample F8, F16, A6B6, A6B10, F4-A6B10, and F8-A6B10 are shown in Fig. 3. In sample F8 and F16, the contents of thorium decreased from 19,680 ppm to 17075 ppm while in sample A6B6 and A6B10, it increased from $21937 \mathrm{ppm}$ to $22707 \mathrm{ppm}$. The significant enhancement occured in sample F-AB and the visible residue contents of thorium in sample F4-A6B10 is 19490 ppm while in F8-A6B10 it is $25850 \mathrm{ppm}$.

In Fig. 4, BTS-RQS result reflects changes in the uranium contents, from $2731 \mathrm{ppm}$ in BTS to $3212 \mathrm{ppm}$ in BTS-RQS.

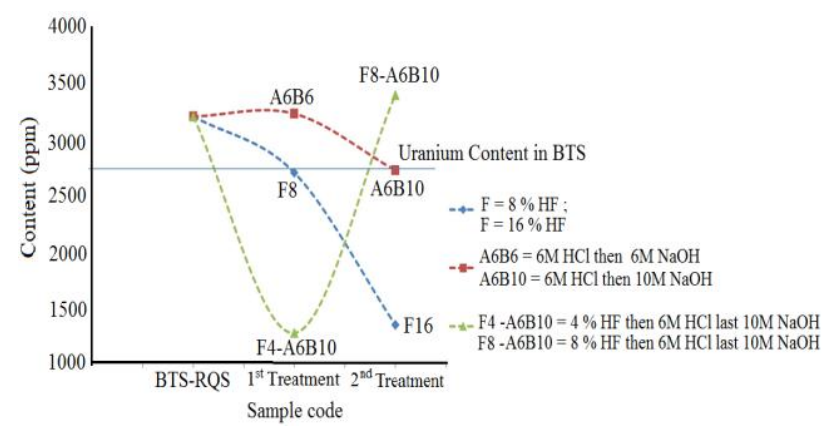

Fig. 4. Uranium content in BTS residue with various treatment conditions.

The contents of uranium in sample F8, F16, A6B6, A6B10, F4-A6B10, and F8-A6B10 are given in Fig. 3. In sample F8 and F16, the contents of uranium decreased from $2708 \mathrm{ppm}$ to $1347 \mathrm{ppm}$ 
while in sample A6B10 and A6B6, they decreased from $3237 \mathrm{ppm}$ to $2730 \mathrm{ppm}$. A significant enhancement occured in sample $\mathrm{F}-\mathrm{AB}$, in which the residues of sample $\mathrm{F} 4-\mathrm{A} 6 \mathrm{~B} 10$ was $1275 \mathrm{ppm}$ and that of F8-A6B10 was 3404 ppm.

Due to a concentration increase in hydrochloric acid in sample $\mathrm{F}$ which resulted in a decrease in the contents of thorium and uranium, the experiments on sample F-AB used $4 \%$ and $8 \% \mathrm{HF}$.

Leaching of BTS with $\mathrm{HCl}$ indicated its influence on extraction of rare-earth elements. The parameters used in the investigation were acid concentration, temperature, particle size, the ratio of solid/liquid, the stirring rate of dissolution, and contact time. The result of this research is that the stirring speed parameter has no significant impacts on the extraction of rare-earth elements [20]. The common parameters that are examined both in this study and the REE extraction study referred are solvent concentration, the ratio of solid/liquid, and temperature. Table 4 presents those common parameters.

Table 4. The common research parameters of Bangka tin slag

\begin{tabular}{lcc}
\hline \multicolumn{1}{c}{ Parametre } & $\begin{array}{c}\text { Radioactive elements } \\
\text { Content }\end{array}$ & $\begin{array}{c}\text { REE } \\
\text { Extraction }\end{array}$ \\
\hline Acid Concentration & HF 8\%-HCl 6M-NaOH 10M & $2 \mathrm{M}$ \\
S/L (gram $/ \mathrm{mL})$ & 20 & 15 \\
Temperature $\left({ }^{\circ} \mathrm{C}\right)$ & 25 & 40 \\
\hline
\end{tabular}

The next discussion is about contact time and particle size. This research was conducted with contact time of two hours for sample F, 12 hours for sample $\mathrm{AB}$, and 14 hours for sample $\mathrm{F}-\mathrm{AB}$. To shorten the contact time, the temperature was raised. In the investigation of REE extraction of BTS, the optimum temperature, $40{ }^{\circ} \mathrm{C}$, and the refinement of particle size could expand the contact surface of BTS solids and solvent.

Sample F8-A6B10 produced the optimal concentrations of thorium and uranium at 25850 ppm and 3404 ppm respectively.

\section{CONCLUSION}

The dissolution of BTS samples F, AB, and F-AB are summarized as follows: (i) The samples of both BTS and BTS-RQS do not show an increase in thorium contents, (ii) The contents of uranium in BTS-RQS are greater than those in BTS, (iii) Samples dissolved in hydrochloric acid shows no increases in uranium and thorium contents, whereas a decrease occurs in $\mathrm{SiO}_{2}$ contents, (iv) The samples which were dissolved in $8 \% \mathrm{HF}$, washed and dried; then dissolved into $6 \mathrm{M} \mathrm{HCl}$, washed and dried; and finally dissolved into
$10 \mathrm{M} \mathrm{NaOH}$ result in the optimum contents of uranium $25850 \mathrm{ppm}$ and thorium $3404 \mathrm{ppm}$.

\section{ACKNOWLEDGMENT}

The authors would like to thank Ang Kok Djiang, Dr. Ir. Haryanti Samekto, Adi Winarta MT, and Dr. Muhammad Amin MT for supporting this paper and giving valuable comments. We also thank Dr.rer.nat. Agustino Zulys M.Sc. for thoughtful discussions, and the National Nuclear Energy Agency of Indonesia.

\section{REFERENCES}

1. M. Anggraini, Separation Process of Radioactive and Rare Earth Elements From Slag II of Tin Roasting, Master Thesis, Institut Teknologi Sepuluh Nopember (2016).

2. L.J. Molofsky, D. Killick, M.N. Ducea et al., Journal Archaeol. Sci. 50 (2014) 440.

3. H. Liu and Z. Pan, Ann. ICRP 41 (2012) 343.

4. I.A. Alnour, H. Wagiran, N. Ibrahim et al., J. Radioanal. Nucl. Chem. 303 (2015) 1877.

5. Syarbaini, A. Warsona and D. Iskandar, Atom Indonesia 40 (2014) 27.

6. H. Syaeful, I.G. Sukadana and Sumaryanto, Atom Indonesia 40 (2014) 33.

7. M.C. Mauriello, C. Sbordone, P. Montuori et al., Toxicol. Lett. 272 (2017) 8.

8. F. Akter, F. Hafiz, M.A.S. Haque et al., Atom Indonesia 40 (2014) 97.

9. B. Sunilkumar and V. Padmasubashini, Explor. Res. At. Miner. 23 (2013) 79.

10. M.Y. Meor Sulaiman, N.S. Kamaruzaman and A.K. Zahari, Waste Mater. Sci. Forum 840 (2016) 410.

11. M.Y. Meor Sulaiman and M. Muslimin, J. Nucl. Relat. Technol. 4 (2016) 177.

12. A. Mutia, B. Sarono, W. Waluyo et al., Eksplorium 36 (2015) 125.

13. S. Permana, J.W. Soedarsono, A. Rustandi et al., IOP Conf. Series : Materials Science and Engineering 012006 (2016) 10.

14. N.M. Piatak, M.B. Parsons and R.R. Seal, Appl. Geochem. 57 (2015) 236.

15. S.I. Angadi, T. Sreenivas, H.-S. Jeon et al., Miner. Eng. 70 (2015) 178.

16. M.Y. Sulaiman, Sci. Total Environ. 131 (1993) 187. 
17. I.G.E. Ibeanu, J. Environ. Radioact. 64 (2003) 59.

18. J.S. Judge, J. Electrochem. Soc. 118 (1971) 1772 .
19. J.U. Odo, W.C. Okafor, S.O. Ekpe et al., Int. J. Sci. Res. Publ. 4 (2014) 1.

20. K. Trinopiawan, M.Z. Mubarok, J. Mellawati et al., Eksplorium 37 (2016) 41. (in Indonesian) 